\title{
Guimarães Rosa: o cantador das veredas imerso na modernidade
}

\author{
Luiz Antônio de Carvalho Valverde
}

E vi um itambé de pedra muito lisa; subi lá. Mandei os homens ficassem embaixo, eles outros esperavam. Minha influência de afã, alegria em artes, não padecesse de se estorvar em monte de pessoas nenhumas. De despico, olhei: eles nem careciam de ter nomes - por um querer meu, para viver e morrer, era que valiam. Tinham me dado em mão o brinquedo do mundo.

Guimarães Rosa

Grande Sertão: veredas

Esta cena reporta o momento da primeira saída de Riobaldo, figura central de Grande Sertão veredas, após ter assumido a chefia do bando de jagunços. Guimarães Rosa, vestindo a pele daquela personagem como narrador, não nos promete um herói levado por ideais superiores, grandes virtudes, num sertão ermo, que tem nas narrativas da oralidade, carregadas de feitos memoráveis de seus heróis, o discurso de aprendizagem daquele universo. Isso não ocorre porque dois são os mundos que perpassam a narrativa: o do sertão, onde vão se dar os episódios, e o do autor, que é um homem que transita no tempo da modernidade, e isso vai contaminar sua escritura, definindo a maneira como irá tratar o material de que dispõe.

Desse modo, sua narrativa vai oscilar entre a fronteira bárbara e bucólica, uma idade prístina que tem seu arcabouço no tempo mítico, forjado na brutalidade das relações humanas, e a ótica enviesada do narrador Riobaldo, que vai estar dentro e fora daquele mundo, porque o flagra em sua beleza e mistério, guardando, entretanto, o olhar crítico. $\mathrm{O}$ bucolismo é uma constante nas páginas de Grande Sertão: Veredas:

Mas, tem horas em que me pergunto: se melhor não seja a gente tivesse de sair nunca do sertão. Ali era bonito, sim senhor. Não se tinha perigos em vista, não se carecia de fazer nada. (...) Quando não ventava, o sol vinha todo forte. Todo dia se comia bom peixe novo, pescado fácil: curimatã ou dourado; cozinheiro era o Paspe - fazia pirão com fartura, e dividia a cachaça alta. Também razoável se caçava. A vigiação era revezada, de irmãos e irmãos, nunca faltava tempo para à-toa se permanecer. (p.250) 
O tempo primeiro da coletividade dos caçadores-pescadores irmanados está aí presente. Temos assim um bucolismo de dimensão ideológica, amparado no mito da Idade do Ouro, mas não em estado puro. Isto poderíamos encontrar nas narrativas de um tempo anterior ao século IX a.C..Hesíodo, segundo Raymond Williams (1989), concebe as origens do bucolismo na literatura, sob influência do mito da Idade do Ouro, como um tempo muito distante. Podemos notar na passagem acima um tempo outro, quando o narrador fala “... se melhor não seja a gente tivesse de sair nunca do sertão.” O ponto de vista que se contrapõe a essa imagem é o de um tempo e lugar colocados como parâmetro, talvez o tempo e lugar da civilização urbana e moderna e por isso mesmo, tempo de busca do Locus amenus idealizado, atravessado por ideologias. De outra sorte, se tomarmos o trecho de Grande Sertão: Veredas que acima serve de epígrafe, talvez possamos verificar o que Raymond Willians constatou em relação ao bucolismo de Teócrito: "é bem evidente um certo grau de elaboração e artifício, particularmente na utilização de dialetos literários.”(p.29).

O dialeto de que faz uso Guimarães Rosa é o da comunidade sertaneja, no intuito de estabelecer a diferença, valorizando a matriz cultural regional. Utiliza-se da norma linguística local como forma de resistência a padrões universalizantes, buscando, por outro lado, enriquecer a cultura central nacional. O autor reelabora o dialeto, não o apresenta de forma crua, antes enriquece-o em estilo e extensão, acrescentando-lhe novas possibilidades, novas expressões, fazendo uso do experimentalismo linguístico, que manipula no limite do estranhamento. As imagens que assim despertam trazem, no entanto, signos insofismáveis da cultura universal. Temos aí a imagem do chefe que contempla seu povo de um patamar mais elevado.

O líder cumpre o ritual de sua autocoroação. Age como o orador, aquele que tem voz, em contraposição àqueles que "nem careciam de ter nomes". A narrativa flagra um tempo, em que se dá a anulação do ser pela total despersonalização do ente humano. As pessoas estão aí "para viver e morrer" ao simples desejo daqueles que as governam. O narrador tem conhecimento claro destes símbolos, manipulados pelos opressores desde os primórdios, num tempo posterior à coletividade bucólica. Riobaldo representa o protótipo dos ditadores, consciente - ou manipulado por forças que o transcendem - do papel das massas como objeto de manobra para a consecução de seus desígnios. E nisso podemos ver o engajamento do autor, que aqui toma o partido dos deserdados ao denunciar, não discursivamente, mas imageticamente, como agem, nas mais das vezes, aqueles que, egressos das massas, quando mal acabam de assumir o poder. 
A crítica do autor assume o caráter de denúncia de uma humanidade decaída, que perdeu o sentido de coletividade. O material linguístico, de que faz uso Guimarães Rosa, é arcaico. Foi colhido em suas andanças pelo sertão. Quase imune a influências externas que o pudessem levar a uma evolução mais rápida, se constitui na matéria-prima que vai receber o toque do mestre, e com ele o espírito da modernidade. Segundo Mary L. Daniel, “... o mundo do Guimarães Rosa é tudo menos unilateral e a inter-relação existente entre os múltiplos aspectos ou níveis da realidade experimentada por ele constitui uma das principais preocupações do autor.” (DANIEL, 1968, p. 41) Segundo a mesma autora, "o alto grau de conhecimento científico atingido por ele, nas suas viagens de investigação, a sua erudição nas línguas e literaturas clássicas e modernas, na gramática, e na técnica da composição, todos estes fatores lhe proporcionam uma mina riquíssima de matéria-prima...” (p.19)

Temos, assim, de considerar que, por trás do narrador de Grande Sertão, existe o autor físico, homem urbano, civilizado e cidadão do mundo, constituindo a "sintonia fina", o estrato mais sutil que aflora das "características essenciais que estariam na raiz dos modos de pensar, sentir, agir", (PESAVENTO, 1999, P.13) e que perpassa o modo como o narrador vai operar sua visão de mundo. O mundo de Riobaldo é o mundo-sertão, lírico e único, universalizado na medida em que o autor toca, sutilmente, nas grandes questões do ser humano. Resvala pelo épico, mas não o assume, pois sua beleza selvagem neste mundo perdido está conspurcada pela forma plural de ver o mundo, em que afirmação e negação, elogio e crítica vão ser a marca de nenhum lugar do narrador. Emil Staiger afirma que:

Nós, mais modernos, aproximamo-nos de qualquer figura com um preconceito. O preconceito consiste em homenagear cada personalidade a partir de ideias e valores fixos. Medimos ideias e valores por um padrão (...) O poeta épico desconhece preconceitos.(...) a humanidade não pode, em tradição indissolúvel, voltar ao plano do épico e satisfazer-se com simples registro de fatos, depois que se começou o relacionamento lógico, e a subordinação das partes. (STAIGER, 1993, p.106)

Riobaldo encarna o homem perdido, dividido entre matar e não matar, entre o amor irrefreável e a contenção do instinto. A inocência, que dá o impulso unívoco, próprio das culturas jovens, foi perdida. Por trás de Riobaldo está um Guimarães Rosa com sua visão de modernidade e falência do discurso enquanto possibilidade de representação de um "eu coerente", como diria Stuart Hall (2000, p.13), atestando seu deslocamento no mundo. Considerando, porém, mais atentamente a questão do preconceito levantada por Staiger, poderemos aventar que Guimarães Rosa tem essa visão perturbadora que joga com o preconceito para poder anulá-lo. Lúcia Helena Vianna vê no desnudamento de Diadorim o “abismo do erro, do logro. (...) O desespero soluçado pelo jagunço bem pode expressar o 
dilaceramento que se promove com o arrancar das máscaras." (VIANNA, 1999, p. 99) Nesse ponto, Guimarães Rosa estaria reinstaurando o tempo primeiro das sensações puras e do olhar inaugural.

Riobaldo encarna o espírito da modernidade não acalentando nenhuma certeza. Apresenta-se como o anti-herói, bandido, a encampar poderes e a encetar a manipulação de sua gente. Após assumir a chefia do bando, aparta-se da massa anônima. Sobe num lajedo, como para meditar, mas o que aí se dá é um reconhecimento, um tipo de reinserção na realidade, com uma nova ótica. Contempla o mundo à sua volta e contempla-se no poder que junge a cabroeira como animais de mando, disponíveis, ao menor riscado das palavrasde-ordem, para matar e morrer. O autor mostra nessa cena - se a despirmos de seus elementos mágicos e míticos - a fraqueza do espírito humano, e coloca o homem como joguete do destino, não como sujeito de sua história, mas como fruto dos meios e acontecimentos que o dirigem. Despe o homem de toda sua humanidade para colocá-lo como animal que age segundo padrões invariáveis através do tempo.

Riobaldo passa por um processo de transmutação. Antes de assumir a chefia, que se dá simbolicamente através das "artes do Tinhoso", com quem fizera pacto, encarnava a coletividade dos jagunços irmanados por um ideal de vingança do assassinato de Joca Ramiro, perpetrado por Hermógenes. Passa, então, por um “ajuste da personalidade a fim de operar num plano superior.” (CANDIDO, 1995, p.170) Não se trata de uma ação comum a ser levada a cabo por um simples jagunço no cotidiano da brutalidade interiorana das Minas Gerais. A ação levada a efeito pelo personagem vai se passar num plano mitológico-simbólico em que a realidade é apenas o cenário para o desenrolar dos acontecimentos. A metamorfose causa-lhe espanto. Personagem, antes, ensimesmado, de poucas palavras, Riobaldo flagra-se, de repente, falando com desenvoltura, seguro de si. Mas, antes que falante, passa a ser falado pelas palavras que brotam da sua boca, ficando admirado com o que está se passando:

Como por um rasgo, para solércias, dei o cabresto ao Fafafa. Disse:- "Tu desarreia, amilha e escova, tu trata dele..."; e isso fiz, porque o Fafafa, que tanto gostava simples de cavalos, era o prestante para cuidar dum animal, em mesmo que dele não sendo. Mas eu tinha dado uma ordem. Assim me refiz. (ROSA, 1986, p. 380) ${ }^{2}$

Encarna o homem diante do mistério. Antes, apenas um joguete do destino, agora, pegando na roda do mundo para fazê-lo girar e governar. É o mito da queda, que olhado pela ótica secular, representa a ascensão para o estado de humanização, a saída do estado indiferenciado para o estágio superior de assunção das prerrogativas humanas. Os atos de

\footnotetext{
2 As próximas referências serão dessa obra.
} 
Riobaldo ganham espontaneidade, sente-se tocado por forças que desconhece, mas que the conferem uma sensação de invencibilidade, com o mal e acima do mal: "Esbarrei em meu caminhar, fiquei assim parado, assim mesmo. O medo nenhum: eu estava forro, glorial, assegurado; quem ia conseguir audácias para atirar em mim?.”(p.38)

Guimarães Rosa opera no patamar simbólico dos que não têm voz, a articular o conserto do mundo pela magia e pelo mito, num contexto marcado pela brutalidade e concepção telúrica. Articula uma nova visão de mundo, uma ordem que pode ser desordem, tendo em vista os padrões ditos civilizados. Suzi Sperber afirma que, para Riobaldo, como propõe Diadorim, vencer o medo é a missão fundamental:

Representa vencer os condicionamentos e determinismos do sistema vigente, da visão de mundo dominante imposta ao dominado. Uma forma de conhecimento que lutará contra as características do conhecimento dominante: logos, teorização e intelectualismo. A desordem do dominado tem normas que, uma vez conhecidas, corrigirão a relação política. (SPERBER, 1982, p.75)

As transformações no mundo ficcional de Guimarães Rosa não ocorrem através da luta e do embate político e ideológico, daí ser chamado de escritor não engajado. Mas precisaria cair no discurso panfletário, na crítica social aberta, defender as ideias e os pensadores de plantão, para ser considerado engajado? Guimarães Rosa não discursa, faz uso das palavras para apresentar-nos imagens de intenso lirismo, imagens essas que falam por si, sem intermediação de sentidos antecipados pelo discurso de época, ou maneirismos. Ao estampar a "estrutura profunda" de nossa índole selvagem, contextualizando-a nos sertões, para vazar para o mundo, não estaria Guimarães Rosa sendo no mínimo panfletário? Panfletos sem palavras, porque elaborados com palavras desenraizadas de seus usos habituais e, portanto, apenas imagens, como no cinema mudo, tomando partido de nossa humanidade sertaneja, e constituindo-se em discurso de fundação da nacionalidade.

Em Alfredo Bosi, podemos encontrar sustentação para esta ideia de engajamento nos estratos mais refinados, em que o sentido de libertação parte da base da cultura arcaica, e não de sistemas amadurecidos em outros contextos.

Guimarães Rosa entra em sintonia com essa "alma de um mundo sem alma", como Marx define com o maior dos realismos a religião dos oprimidos. A sua narrativa, que parece a tantos ardidamente moderna e até mesmo experimental pela ousadia das soluções formais, realiza, com as artimanhas da linguagem, uma nova tradução do pensamento arcaicopopular. (BOSI, 1988, p.23)

Alfredo Bosi, ao analisar os contos de Guimarães Rosa, assinala que a passagem do estado de falta para o de plenitude se dá por meios mágicos: “.... os contos não correm sobre 
os trilhos de uma história de necessidades, mas relatam como, através de processos de suplência afetiva e simbólica, essas mesmas criaturas conhecerão a passagem para o reino da liberdade (p.22-3).

Guimarães Rosa opera elementos simbólicos em substituição aos elementos lógicos como uma forma peculiar de engajamento nas discussões do seu mundo, das carências de sua gente e sua suplência por meios mágicos. Ao operar nesse caldo de cultura não o faz de maneira acrítica, ingênua, mergulhado nos elementos como se deles participasse numa "pastoral". O próprio narrador, Riobaldo, se declara esperançoso de um novo tempo, civilizatório, nos sertões. Suzi Sperber diz que Diadorim "enfrenta o velho mundo para acabar com ele (...) Engendra um novo tempo. É a volta ao caos primordial e daí para outra organização do mundo.”(SPERBER, 1982, p. 94) Esse mundo brutal retratado por Guimarães Rosa nos enseja mergulhar no inconsciente coletivo e aí buscar oxigênio para nossa coletividade, brasileira, em processo de afirmação.

O recurso à magia, ao mito, ao maravilhoso, é a vereda que tomou o autor a cavaleiro desse mundo arcaico, que parece ser nosso mundo irrevogável, ponto de fusão de nossa gente, perpassando instâncias do seu autoconhecimento, e que vai documentado pelo autor no limiar do seu desaparecimento. Do outro lado da moeda, o autor nos revela o seu mundo civilizado, alicerçado na razão, no progresso material e tão carente de valores e, mesmo, de sum sentido para existir.

\section{REFERÊNCIAS}

BERMAN, Marshall. Tudo que sólido desmancha no ar: a aventura da modernidade. São

Paulo, Schwarcz Ltda., 1992.

BOSI, Alfredo. Céu, inferno. In: Céu, inferno. Ensaios de crítica literária e ideológica. São Paulo, Ática, 1988.

CANDIDO, Antonio. Jagunços mineiros de Cláudio a Guimarães Rosa. In: Vários Escritos. São Paulo, Livraria Duas Cidades, 1995.

DANIEL, Mary L. João Guimarães Rosa: travessia literária. Rio de Janeiro, José Olímpio Editora, 1968.

HALL, Stuart. A identidade cultural na pós-modernidade. Rio de Janeiro, DP\&A, 2000.

PESAVENTO, Sandra J.. O imaginário da cidade. Visões literárias do urbano. Porto Alegre, Editora da Universidade/UFRGS, 1999. 
ROSA, João Guimarães. Grande Sertão: Veredas. Rio de Janeiro, Editora Nova Fronteira, 1986.

SPERBER, Suzi F.. Guimarães Rosa: signo e sentimento. São Paulo, Ática, 1982.

STAIGER, Emil. Conceitos fundamentais da poética. Rio de Janeiro, Tempo Brasileiro, 1993.

VENUTI, Laurence. The translator Invisibility. New York, Routledge. 1995.

VIANNA, Lúcia H. Cenas de amor e morte na ficção brasileira: o jogo dramático da relação homem-mulher na literatura. Niterói, EdUFF, 1999.

WILLIAMS, Raymond. O campo e a cidade na história e na literatura. São Paulo, Companhia das Letras, 1989. 